\title{
プリント配線板製造におけるダイレクトプレーティング技術
}

\author{
安 藤 直 美 $^{\mathrm{a}}$ \\ a マクダーミッド・パフォーマンス・ソリューションズ・ジャパン株)(
}

\section{Direct Plating in Printed Circuit Board Manufacturing}

\section{Naomi ANDO ${ }^{a}$}

${ }^{a}$ MacDermid Performance Solutions Japan K.K. (480-28, Higashi-toyoda, Hiratsuka-shi, Kanagawa 254-0082)

Keywords : Direct Plating, Metallization, Carbon, Rigid Printed Circuit Board, Flexible Printed Circuit Board, MSAP

\section{1.はじめに}

2018 年のプリント配線板市場は, 堅実な成長を見せている。 スマートフォン, 自動車の電子化などが成長の牽引要素と なっている ${ }^{1)}$ 。

スマートフォンは, 普及に伴い成長鈍化が懸念されている ものの，年間 15 億台という大きな市場規模，モデル毎の技 術革新は, プリント配線板を含む周辺技術の変化をもたらし ている。技術上の大きな変化の一例として, 従来パッケージ 基板の技術であったMSAP 法がプリント配線板 (メイン基 板)に採用されたことがあげられる。MSAP 法は微細回路が 可能な製造技術で，アプリケーションプロセッサー，デバイ スの高集積化に伴うパッケージの端子数の増加に対応すると 同時に, 基板面積割合を減少させてバッテリー容量を増加さ せることに貢献している。

また, フレキシブル基板においても, スマートフォン用途 の比率は高く, 液晶ドライバ, カメラモジュール, アンテナ など，様々なパーツに用いられている。

本稿では, ダイレクトプレーティング技術について解説し, 上記 MSAP 法への適用例について, 紹介する。

\section{2. ダイレクトプレーティング技術}

ダイレクトプレーティングとは, 不導体部分の導電化を, 無電解銅めっきを用いずに行う技術である。

プリント配線板の導体は，基材の銅䇴や電解銅めっきで主 に平面方向に配線される。導体層が複数層ある両面板, 多層 板では, 導体層間の接続が必要で, 厚み方向にあけたスルー ホールあるいはビアホールで接続する。電解銅めっきを行え ないホール内の不導体部分の導電化工程は, 前処理によって 付与したパラジウムを触媒とする無電解銅めっきが広く使わ れてきた。無電解銅めっきによる導電化後は, 電解銅めっき によって必要な導体厚みまでめっきを行うことができる。

プリント配線板の導電化処理において, 無電解銅めっきは, 長年にわたる技術の蓄積に基づいた，工業的に成熟したプロ セスである。触媒に用いられる高価なパラジウム, 無電解銅
めっき液に用いられる劇物のホルマリン, 大量に排出される キレート含有の無電解銅めっき液の廃液処理など, 問題点も 多く抱えるものの, 1960 年代の工業的な利用の開始から現 在まで，半世紀以上にわたって主流のプロセスとなっている。

ダイレクトプレーティングは, パラジウム付与の前処理及 び無電解銅めっきに置き換えて用いられるプロセスで，銅の 代わりに用いられる導電性物質によって 3 つの系統に分類さ れる。

$1 つ$ 目は, 導電性ポリマー系である。過マンガン酸デスミ アに類似した工程で導電化の必要な部分に二酸化マンガンを 付与後, そこにモノマーを反応させる。その後モノマーをポ リマー化して導電性を得る。

$2 つ$ 目は, パラジウム系である。無電解銅めっきの前処理 と同様の工程でパラジウムを付与した後, 導電性を上げる処 理が行われる。導電化の必要な部分だけではなく銅䇴上にも パラジウムが付与されるため, 最後に銅箔をエッチングして パラジウムを除去する。

3つ目は, カーボン系である。静電吸着によりカーボンを 付与し, 温風乾燥で固着させる。導電化の必要な部分だけで はなく銅䇴上にもカーボンが付与されるため, 最後に銅箔を エッチングしてカーボンを除去する。

ダイレクトプレーティングは, 先に述べた無電解銅めっき の問題点をクリアし，無電解銅めっき液でのダイナミックな 化学反応を制御する必要がなく, 管理が容易である。用いる 導電性物質 (以降導電化物質と呼ぶ) によっては, 無電解銅 めっきより大幅なコストダウンが望める。

一方で, 導電化物質の抵抗が銅より高く, 電解銅めっきの つきまわりには不利である。また, 導電化の不要な銅表面上 の導電化物質は, 後続の電解銅めっきとの密着性低下の原因 となる。すなわち, 導電化の必要な部分には確実に付与し, 導 電化の不要な銅表面上には付与しないことがポイントとなる。 導電化物質が基板全体に付与されるタイプのダイレクトプ レーティングは, 銅表面からの導電化物質の除去が必要であ る。導電化物質の除去は, 銅表面のマイクロエッチングによっ て, 銅表面と共に導電化物質を除去することで行われる。こ 
の性質は, しばしば「選択性がない」「後エッチングプロセス」 と言われ，ダイレクトプレーティングの弱点とされてきた。

銅表面と導電化が必要な樹脂部などの界面においては, 計 算上はエッチング厚み分の導電化物質が付与されていない部 分が生じる。そのため, エッチング量は必要最小限にコント ロールすることが重要となる。

\section{3. ダイレクトプレーティングの歴史}

先に述べたように，プリント配線板の導電化処理において， 無電解銅めっきは，長年にわたる技術の蓄積に基づいた，工 業的に成熟したプロセスであり，1960 年代の工業的な利用 の開始から現在まで，半世紀以上にわたって主流のプロセス となっている。

これに対して，1980 年代から 1990 年代にかけて，ダイレ クトプレーティングの提案が盛んに行われた。1990年代前 半には, 導電性ポリマー系 2 プロセス, パラジウム系 15 プ ロセス, カーボン系 2 プロセスが発表されている ${ }^{2)}$

プロセスのコントロールは, 薬品の要因だけではなく, 処 理装置の要因も大きく関与し, そのノウハウの確立が未熟で あったダイレクトプレーティングプロセスの多くは, 市場に 広く受け入れられなかった。1990 年代前半には 20 近いプロ セスが発表されていたが, 現在, 市場で量産に用いられてい る主要なプロセスはその半数以下と推定される。

その中でフレキシブル基板においては, 当初の 1990 年代 前半より導入され，広く使われて今日に至っている。主な理 由は以下の 2 点である。1つ目は, フレキシブル基板は, 薄く, 柔軟性があり, 製造工程での取り扱いが難しいこと, 2 つ目は, 使用される基材がアルカリに弱いポリイミドであることであ る。コンベア処理でアルカリ性の強い無電解銅めっき薬品を 用いないダイレクトプレーティング，特にカーボン系のダイ レクトプレーティングが多く使われており, その長所がフレ キシブル基板の特徴にマッチングしたものと考える。

フレキシブル基板製造において，カーボン系のダイレクト プレーティングが用いられるようになって，25 年以上が経 過する間に，フレキシブル基板はより微細化し材料，製造工 程も変化したが, ダイレクトプレーティング技術も合わせて 進化を遂げてきている。カーボン系のダイレクトプレーティ ングは，現在ではフレキシブル基板の導電化において世界的 に主流のプロセスと言えるだろう。

リジッド基板においては，現在でも無電解銅めっきが主流
であるが, 徐々にではあるがダイレクトプレーティングの採 用が進んできた。1990年代半ば以降のコスト競争激化を背 景にした台湾メーカーによる採用，2000 年代後半からの, 大手電子機器メーカーの台頭を背景に投資が活発になった韓 国メーカーによる採用, 韓国, 台湾メーカーの中国工場, さ らには中国メーカーと，採用が進んできている。量産の中で, ダイレクトプレーティングの管理技術は向上し，改良が加え られていった。一方で，大きな投資が一段落した日本におい ては，フレキシブル基板における継続的な採用はあったもの の，リジッド基板への広がりは限定的であった。

2017 年, 全世界での前処理を含む無電解銅めっきプロセ スの売上金額は約 5 億ドル，ダイレクトプレーティングの売 上金額は約 0.6 億ドル ${ }^{3)}$ ，金額ベースで導電化プロセス全体 の約 $10 \%$ となっている。ダイレクトプレーティングのラン ニングコストが無電解銅めっきより低いことを考慮すると基 板処理面積による生産量の比率は $10 \%$ よりも多いと思われる。

\section{4. ブラックホールプロセスの概要}

本章では, カーボン系のダイレクトプレーティングプロセ スである弊社ブラックホールプロセスの概要について解説す る。

図 1 にブラックホールプロセスの工程を無電解銅めっき工 程との比較で示す。無電解銅めっきプロセス 7 工程に対して, ブラックホールプロセスは 5 工程, 4 薬品となっている。ブ ラックホールプロセスは, 大きく, 前半 4 ステップ, 3 薬品 のカーボンを付与する工程と, 後半 1 ステップのカーボンを 銅箔から除去する工程に分かれる。

図 2 にスルーホールを示した基板断面図を用いてプロセス
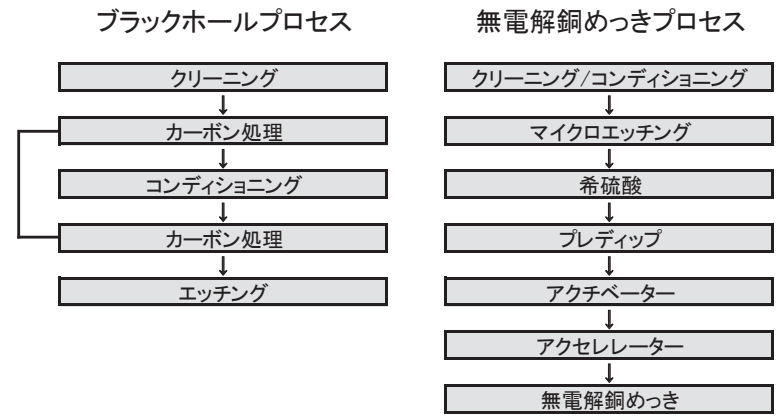

図 1 ブラックホールプロセス, 無電解銅めっきプロセスの 工程比較

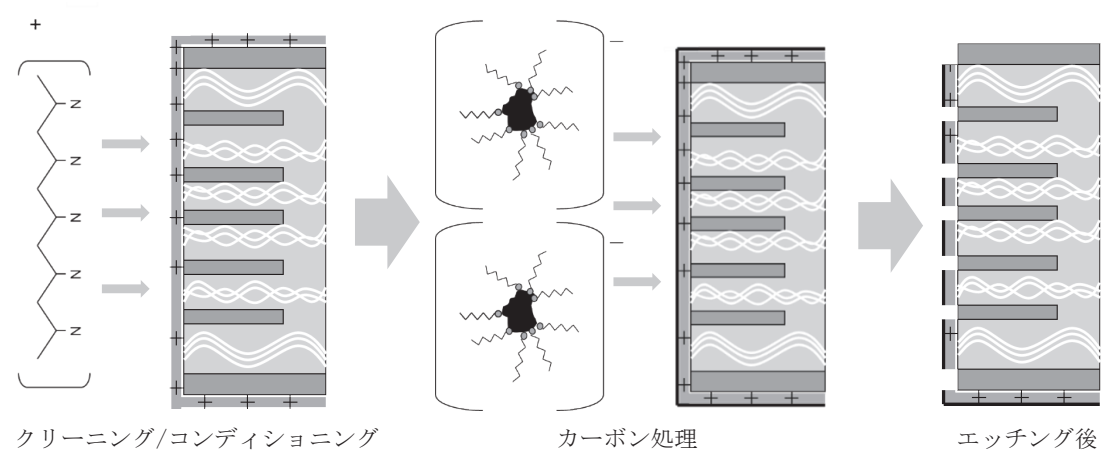

図2 ブラックホールプロセス 


\section{を説明する。}

クリーニングとコンディショニングは, 導電化の必要な微 細な穴に処理液が確実に入るように濡れ性を向上させる機能 を持ち, 基材にプラスの電荷を付与し, その後のカーボンの 吸着の下地を作る。カーボンを密に吸着させて, 電気抵抗を 下げるために, カーボンは 2 回吸着させる。1 回目の前処理 がクリーニング, 2 回目の前処理がコンディショニングである。

カーボン粒子はマイナスの電荷で, カーボン処理液に分散 している。このコロイド溶液は, カーボン粒子の分散を安定 に保つために $\mathrm{pH}$ 緩衝液となっている。このコロイド溶液を 光学的な手法で測定した例を図 3 に示す。図 3 の横軸は粒径 を，縦軸は回答強度を示す。平均粒子径が $100 \mathrm{~nm} \sim 200 \mathrm{~nm}$ 程度であることがわかる。このカーボン粒子はマイナスの電 荷によって，先に付与されたプラス電荷に吸着する。

次に，基板全面に吸着したカーボンを銅表面からエッチン グによって除去する。カーボンが表面銅箔に残ればめっきザ

Size Distribution by Intensity

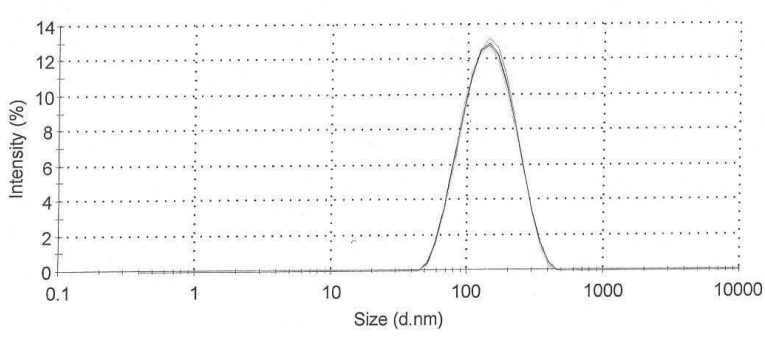

図 3 カーボン粒子径の測定例 (マルバーン・パナリティカル社 ゼータサイザーナノ ZS による)
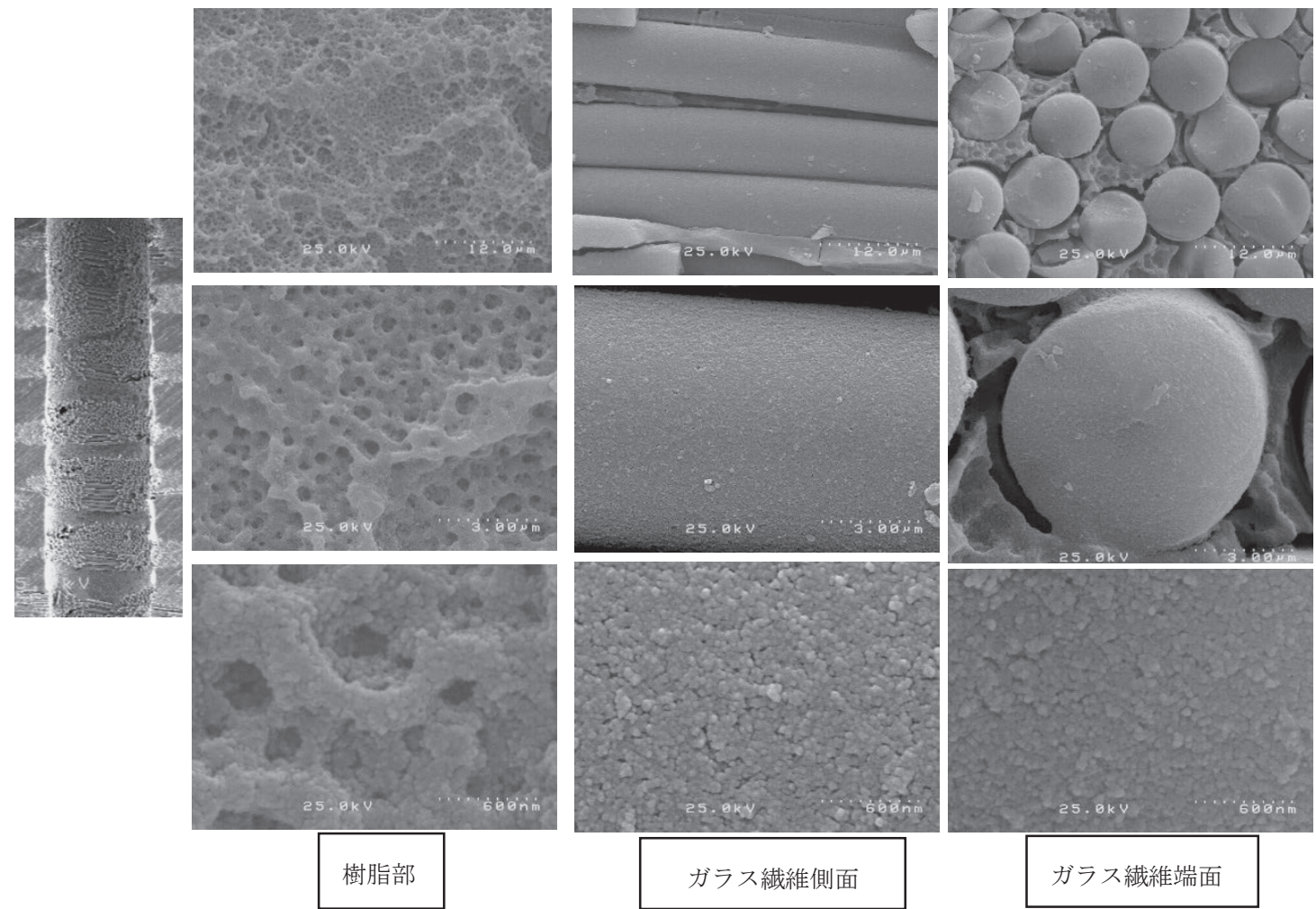

図4 スルーホール内のカーボン粒子吸着状態 
アホール内の樹脂, ガラス䋊維へのカーボンの付与を確実に 行うことと, 表面銅箔, スルーホール内層銅䈃, ビアホール 底面銅箔からの，カーボンの除去を，確実に行うことである。 薬品, 装置仕様の改良によって, 微細なスルーホール, ブラ インドホールヘのカーボン付与, 及び銅䇴からの良好な除去 性が得られるようになっている。

表 1 に弊社ブラックホールプロセスの 1990 年代以降の改 良点を挙げる。

\section{MSAP 法}

プリント配線板の回路形成工程は, 従来サブトラクティブ 法と呼ばれる工程が主流であった。この方法で可能な回路の 配線最小幅はお拈よそ $\mathrm{L} / \mathrm{S}=30 / 30$ 程度である。しかし, パッ ケージ基板や, 先に述ベたスマートフォンのメイン基板のよ うに L/S = 30/30 以下が必要とされる製品が出てきている。

この内 $\mathrm{L} / \mathrm{S}=20 / 20 \sim 30 / 30$ 程度の製品に適用可能な工法

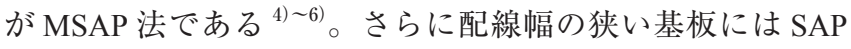
法が適用される。

サブトラクティブ法は, 一般的には $18 \mu \mathrm{m}$ 銅箔の銅張基 板からスタートして，層間接続のため基板全面にめっきを 行った後, 回路間の不要な銅を溶解して回路形成を行う。こ の時，銅表面から行われるエッチングは哚さ方向だけでなく 面方向にも進行するため回路は表面ほど細くなり，回路断面 は台形になる。エッチングする銅厚が厚いほど，細い回路が 形成できない。層間接続のためのめっきは信頼性の観点から 必要な厚み以下には落とせないため, スタートの銅張基板の 銅箔を予めハーフエッチで薄くするなど細い回路のための工 夫があるが，限界がある。

一方で, SAP 法は, 樹脂基板からスタートして, 無電解 銅めっきによる導電化の後, ドライフィルムによるめっきレ ジスト形成後に，層間接続と同時にめっきによる回路形成を 行う。めっきで形成された回路の断面はほぼ矩形で, エッチ ングによる回路よりも細い回路が形成できる。しかし，樹脂 基板への無電解銅めっきの密着性，めっきレジスト除去後の 回路間の不要な無電解銅めっき層のフラッシュエッチングの 制御など難しい課題もある。

MSAP 法は，SAP 法に近い工法であるが，スタートの材 料が SAP 法と異なり，極薄銅箔を用いた銅張基板，あるい は予めハーフエッチにより厚みを薄くした銅張基板からス タートする。工程はSAP 法とほぼ同じで, 無電解銅めっき による導電化の後, ドライフィルムによるめっきレジスト形
成後に，層間接続と同時にめっきによる回路形成を行う。薄 い銅䇴層と無電解銅めっき層を合わせてフラッシュエッチン グする必要があるためSAP 法ほど細い回路は形成できない が，樹脂基板への無電解銅めっきの密着性は懸念されない。

図 6 に, 基板断面から見たサブトラクティブ法と MSAP 法の工程比較を示す。
サブトラクティブ法

12

- $18 \mu$

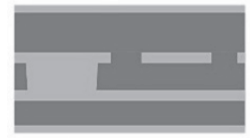

レーザー

加工

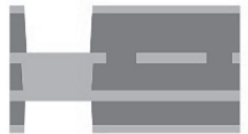

デスミア〜 導電化処理

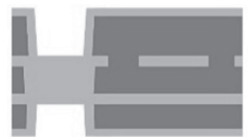

パネル

めつき

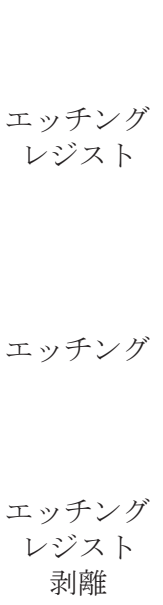

パターン 断面形状
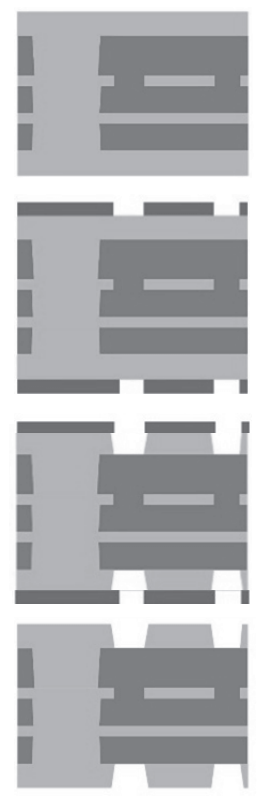

めつき レジスト

パターン

めつき

レーザー

加工

デスミア〜 導電化処理
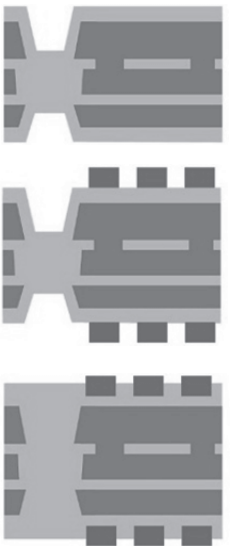

めつき レジスト 剥離

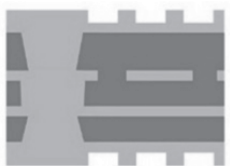

フラッシュ エッチング

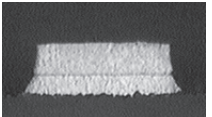

パターン 断面形状

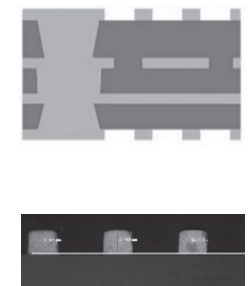

図 6 サブトラクティブ法と MSAP 法

表 1 ブラックホールプロセスの改良ポイント

\begin{tabular}{ll}
\hline 薬品の改良 & \\
\hline クリーナー & $\begin{array}{l}\text { 銅の上に形成し, エッチングにおいて溶解する犠牲皮膜成分の } \\
\text { 採用(少ないエッチング量でカーボン除去可能) }\end{array}$ \\
\hline クリーナー/コンディショナー & 経時劣化の少ない成分への改良 \\
\hline カーボン & めっき伝播の良い組成への改良 \\
\hline エッチング & 長期浴安定性の向上 \\
\hline 装置の改良 & カーボン除去性の良い組成への改良 \\
\hline 液の噴流システム & \\
\hline エッチング & レーザービアホールヘの対応可能な噴流システムへの改良 \\
\hline
\end{tabular}




\section{6. ダイレクトプレーティングの MSAP 法への適用}

ブラックホールプロセスの MSAP 法への適用例を紹介す る。MSAP 法による基板製造において，ブラックホールによ る導電化は既に量産実績がある。本章では, 無電解銅めっき と比較してブラックホール適用の利点を述べ, 弊社日本ラボ での試験結果例を報告する。

表 2 に，同じ銅䇴厚でスタートしたMSAP 法における工 程毎の表面銅厚の変化例について, 無電解銅めっきとの比較 を示す ${ }^{7)}$ 。無電解銅めっきにおいてはそのめっき厚分がプラ スされるのに対して, ブラックホールではエッチング分がマ イナスされる。よって, ドライフィルムラミネート時には, ブラックホールの方が薄くなり，フラッシュエッチングでは, その分少ないエッチング量で行うことができる。

サブトラクティブ法で形成されたコア及び複数のビルド アップ層と, MSAP 法で形成されたビルドアップ層からなる 多層板において，IST サイクル試験を行った。

IST サイクル試験は従来の気相の熱衝撃試験よりも結果が 得られるのが早く近年多く用いられる試験方法で, IPC 規格 に規格化されている。（IPC-TM-650 2.6.26）試験用の専用クー ポンを用いる。クーポンにはパワー回路とセンス回路が設け られており，パワー回路に電流を印加してその発熱により クーポンを熱した後冷却する。1 サイクル 5 分の繰り返しで 回路の接続性を評価する。個別に温度条件, 及び前処理とし て複数のリフローサイクルを設定する。

各層の導電化にブラックホールプロセスと数種類の無電解
銅めっきを組み合わせて評価を行った。ビア底面の接続にお いて無電解銅めっきよりもブラックホールの方が良好である ことが示唆された。カーボンが除去されたビア底面銅箔上に おいては，無電解銅めっき層のような中間層がなく，電解銅 めっきと直接接続できるためと考えられる。

図 7 に弊社ラボでブラックホール〜ビアフィリングめっき を行ったビアホールの断面写真を示す。

次にフレキシブル基板の試験例を示す。基材は，ポリイミ ドフィルム上に，スパッタにより形成された $\mathrm{Ni} / \mathrm{Cr}$ 及び $\mathrm{Cu}$ 層からなる両面板である。表裏の導通のためUVレーザーに よるスルーホールがあけられる。レーザー入射側の径が少し 大きくテーパーのかかったスルーホールが形成される。微細

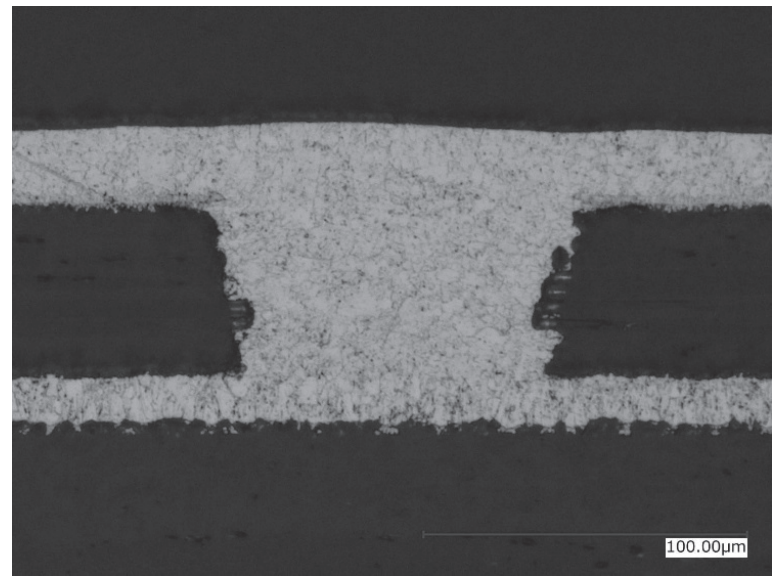

図 7 リジッド基板のブラックホール〜ビアフィリング断面

表 2 MSAP 法における表面銅厚の変化例 ${ }^{7}$

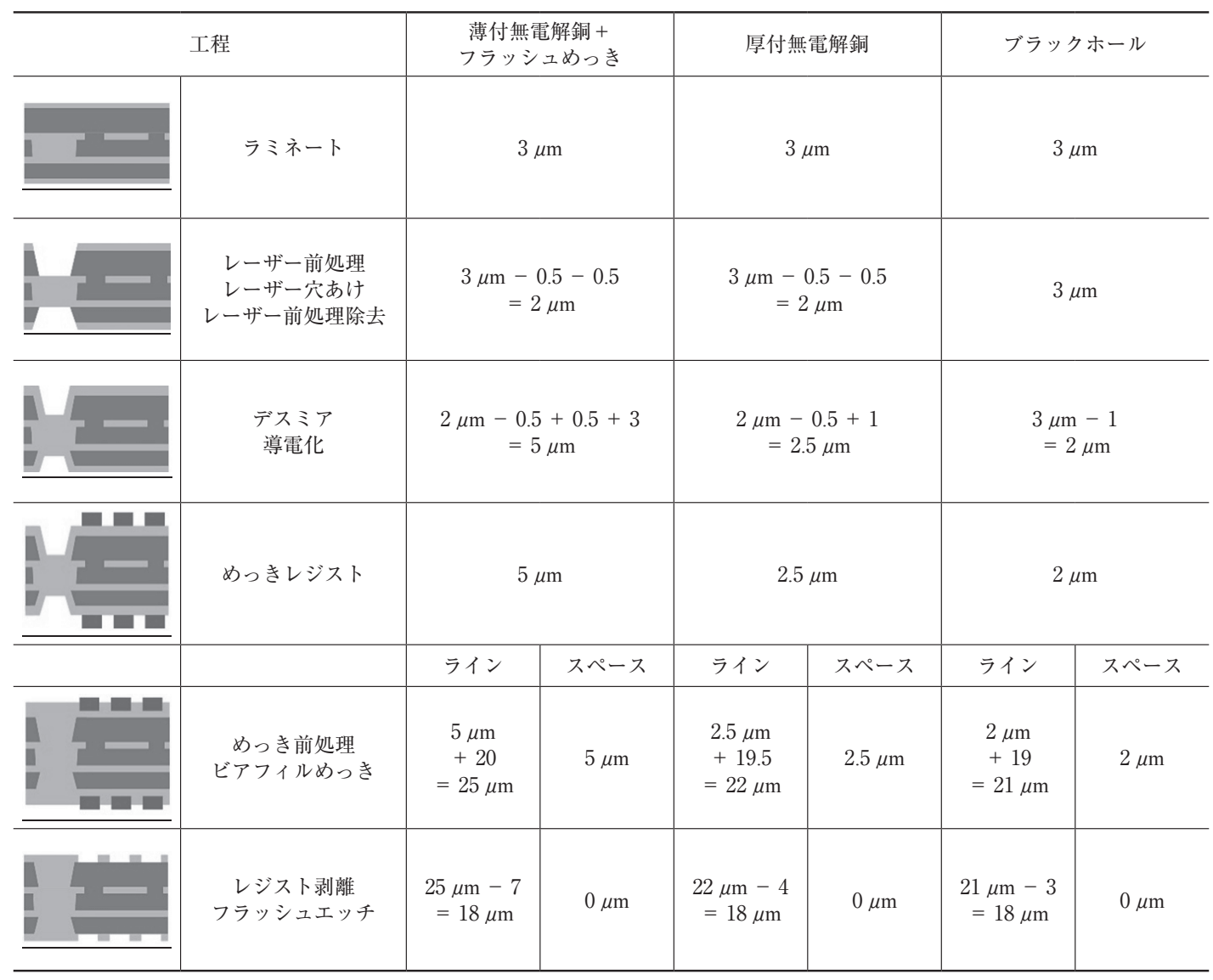




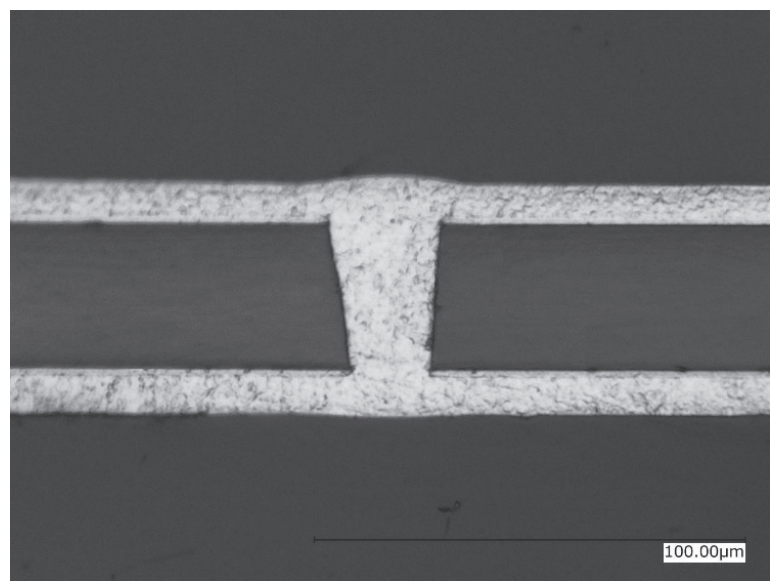

図 8 フレキシブル基板の

ブラックホール〜スルーホールフィリング断面

で板厚が薄いフレキシブル基板においては, RtoR 処理が前 提であり，その点ではブラックホールの実績は充分である。

図 8 に弊社ラボでブラックホール〜スルーホールフィリン グめっきを行ったスルーホールの断面写真を示す。(本来は パターンめっきであるが, 弊社ラボでの写真例はいずれもパ ネルめっきである。）

\section{7.おわりに}

ダイレクトプレーティングは, その本来の性質から全ての
無電解銅めっきに代わるのものではない。例えば SAP 法に おいて基板全面の樹脂へのめっきへの対応は困難である。

しかし適用事例に示したような層間厚みが薄い小径ビア基 板などにおいては，低コスト，信頼性，ハンドリング性，コ ンパクトな処理装置, 作業環境, 廃液処理など, 総合的なメ リットを考慮すると, 無電解銅めっき置き換えの強力な候補 となり得ると考える。

ダイレクトプレーティングは，より厳しくなるコスト競争， 環境対応の要求に対して，1つの解を提供するプロセスであ る。今後とも, 着実にプロセスを改良, 最適化していき, 対 応可能な領域を広げていけるよう精進していく所存である。

(Received January 15, 2019)

\section{文献}

1 ）プリント回路メーカー総覧2018年度版(産業タイムズ社, 2018).

2 ）豊永 実; 表面技術, 44, 599 (1993)

3 ) プリズマークレポート (2018).

4 ）齊藤 武, 若林信一; 表面技術, 68, 480 (2017).

5 ）飯田浩人; 表面技術, 68,488 (2017).

6 ）佐波正浩; 表面技術, 68, 494 (2017).

7 ) R. Bellemare, J. Kologe ; “Achieving fine lines and spaces using MSAP” Printed Circuit Design \& Fab/Circuits Assembly, 26, Nov. 2018 